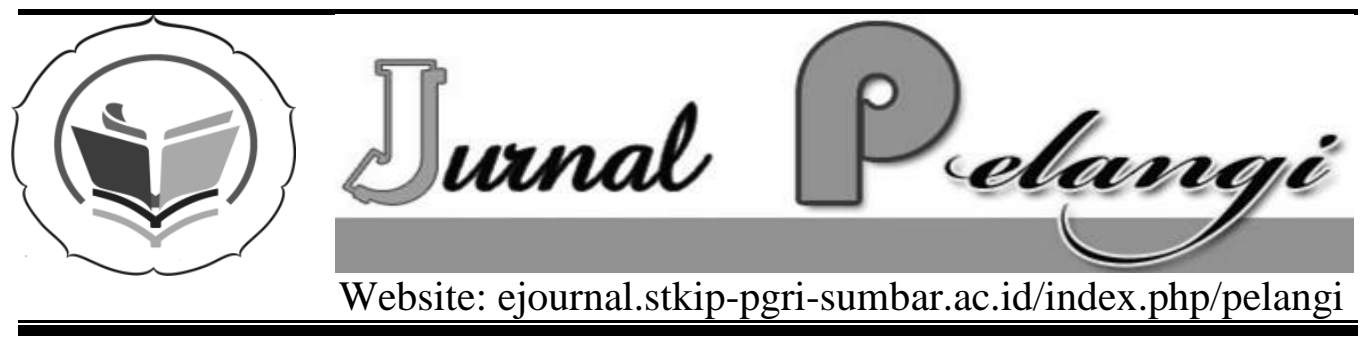

\title{
DEVELOPING A MODIFIED REPERTORY GRID INSTRUMENT FOR ELICITING RESEARCH PARTICIPANT'S PERSONAL CONSTRUCTS
}

\author{
Sri Imelwaty
}

STKIP PGRI Sumatera Barat

imelwaty05@yahoo.com

\section{INFO ARTIKEL}

Diterima :01-01-2014

Disetujui :01-12-2014

Kata Kunci:

Teknik kisi-kisi perbendaharaan, Teori konstruksi pribadi, Konstruksi pribadi

\section{Abstrak}

Aplikasi terdahulu terkait teknik kisi-kisi perbendaharaan dalam mengeksplorasi konstruksi pribadi peserta telah dicatat. Namun, teknik ini bisa dimodifikasi sesuai keperluan pertanyaan penelitian, kondisi peserta dan konteks penelitian. Penelitian ini menyajikan teori konstruksi pribadi yang menyokong teknik kisi-kisi perbendaharaan dan juga mengusulkan cara untuk mengembangkan instrument kisi-kisi perbendaharaan yang dimodifikasi untuk memunculkan konstruksi pribadi guru. Menurut Kelly (1955), seorang psikolog seminal, individu membentuk konstruksi mereka berdasarkan pengamatan dan pengalaman dan konstruksi pribadi ini digunakan untuk menafsirkan peristiwa. Untuk memperoleh konstruksi pribadi peserta mengenai topik yang diteliti, instrument kisi-kisi perbendaharaan, yang dikembangkan berdasarkan Teori Konstruksi Pribadi dari Kelly, bisa dimodifikasi melaluiu jiwa wancara. Setelah melakukan uji coba wawancara, hasil dianalisis untuk mengidentifikasi apakah instrument ini efektif, tidak hanya untuk peserta tetapi juga untuk para peneliti. Instrumen kisi-kisi perbendaharaan yang dimodifikasi harus memungkinkan dan mendukung peserta dalam membentuk dan mengelaborasi konstruksi pribadi mereka. Untuk peneliti, instrument harus membantu untuk mengidentifikasi konstruksi pribadi peserta berdasarkan konsepsi mereka sendiri dan pemahaman terhadap topik yang diteliti. 


Keywords:

Repertory grid technique, personal constructs theory, personal constructs

\begin{tabular}{l} 
Abstract \\
\hline Previous application of the repertory grid technique in \\
exploring participants' personal constructs has been \\
noteworthy. However, this technique could be modified \\
to suit the purposes of the research questions, the \\
conditions of the participants and the context of the \\
study. This paper presents personal constructs theory \\
which underpins the repertory grid technique and it also \\
proposes the ways to developa modified repertory grid \\
instrument for eliciting teachers' personal constructs. \\
According to Kelly (1955), a seminal psychologist, \\
individual forms their constructs based on their \\
observations and experiences and these personal \\
constructs are used to interpret events. To elicit \\
participants' personal constructs regarding the topic \\
under study, the repertory grid instrument, which is \\
developed based on Kelly's Personal Construct Theory, \\
could bemodified through interview trials. After \\
conducting the interview trials, the resultsshould be \\
analyzed to identify whether this instrument is effective \\
not only for participants but also for the researchers. \\
The modified repertory grid instrument should allow \\
and support participants in formalizing and elaborating \\
their personal constructs. For the researchers, the \\
instrument should be helpful to identify the participants' \\
personal constructs based on their own conceptions and \\
understandings toward the topic under study. \\
\hline
\end{tabular}

(Kurz 2011). In addition, a repertory grid interview is used as an interview strategy to elicit verbal commentaries in which individuals exercised choices in assigning meanings which are embodied in their personal constructs (Borg, 2006, p.194).

For a successful application of the repertory grid technique, researchers should be fully aware of the conditions of their research participants. The interview instrument should be effective enough to accomplish the research purposes. To this end, this paper elaborates the theories underpinning this technique and the ways to modify the interview instrumentwhich employs the repertory grid principles to meet 
with the research participants' conditions and the aim of the interviews.

\section{METODE PENELITIAN}

Repertory grid technique for interviewing research participants has been employed by researchers to discover the personal constructs that may influence individual behaviour (Fransella, Bell \& Banister, 2004; Fang, 1996). According to Fransella et al. (2004), "repertory grid technique is, in its multitude of forms, a way of exploring the structure and content of such implicit theories" (p.3). In addition, they claim that every human has implicit theoretical beliefs or construct sub-systems which are linked into the overall theory or a personal construct system. Terrill and Flitman (2002) simplify the definition of repertory grid as "an interviewing method for eliciting people's ideas or opinions about some aspect of reality, expressed in their own personal terminology" (p.2). This means that, the repertory grid method is a tool to gather individuals' opinions of the people in which they are free to use their own words.

Personal construct systems are the theories of a person which are referred to in other psychological approaches as the person's personality, attitudes, habits, reinforcement history, informationcoding system, psychodynamics, concepts, philosophy or central nervous system (Fransella et al., 2004, p.3). According to Kelly
(1955) who developed the theory of personal construct, everyone has his/her own personal ideas, philosophies, and theories about the world (Beail, 1985. p.1). In addition, Beail(1985) explains that" we come to understand the world in which we live by erecting a personally organized system of interpretation or constructs of experienced events" (p.1). In other words, although the system is personal but individuals can make their own interpretations of their experiences, share a view, and appreciate others interpretations.

Regarding an issue of the bias which must be avoided during the research process, the repertory grid technique is useful for articulating the respondents' view on complex topics without interviewer bias (Goffin, 2002). The subjects or the participants' opinions are based on their own and are not formed from the researcher's opinion.

Therefore, the repertory grid technique may enable the researcher to elicit the people's ideas on certain objects and then the participants can express their opinions in their own words or terminology. Furthermore, with respect to exploration of individual's perceptions, this technique is helpful for the researchers to understand the point of view or perceptions of the participants regarding the topic under study. As Huff (1990) in Terrill and Flitman (2002) describe that this technique becomes a tool for 
understanding and describing individual mental contents about particular topics.

There are two main terminologies in the repertory grid technique, 'constructs' and 'elements'. With respect to personal construct, a construct refers to an individual's ways of construing the world.This is based onKelly's (1969) description of the meaning of a construct which he claims as follow:

A construct is like a reference axis. A basic dimension of appraisal, often unverbalised, frequently unsymbolised, and occasionally unsignified in any manner except by the elemental process it governs. Behaviourally it can be regarded as an open channel of movement, and the system of constructs provides each man with his own personal network of action pathways, serving both to limit his movements and to open up to him passages of freedom which otherwise would be psychologically non-existent. (p.293)

Kelly also adds that when a new abstraction was made by someone from out of events, the limitation of the facts from the previous abstraction were being escaped by the person (Fransella et al., 2004). There is an important notion that Kelly retains from all of the definition he offers regarding the constructs. His argument makes the notion of constructs is different from the notion of concept. He argues that constructs are bipolar nature because we never affirm anything without simultaneously denying something (Fransella et al., 2004).
Another simple definition of a construct which is described by Fransella et al. (2004) is "a way in which two or more things alike and thereby different from a third or more things" (p.7). Itbecomes a technique which is known as triadic method for eliciting the constructs. To simplify, Coshall (2000) also describes that constructs are individuals' personal interpretations and assessments of the environment around them.

The next important terminology is the elements. They are the entities which hold individual's opinions or they are the object of the study and the constructs are the attributes of the object (Terrill and Filtman, 2002). It is in accordance to what Fransella et al. (2004) explain that elements are chosen to represent the area in which construing is to be investigated. In other words, elements of the topics under study should not be the same and general. For example, the topic under study is models of cars, thus the elements are Hyundai, Toyota, Honda, etc.

One of the methods for construct elicitation which could be employed within the repertory grid technique is 'laddering'. Hinkle (1965), a student of Kelly, developed this technique to identifying the hierarchical relationships amongst constructs (Terrill and Filtman, 2002; Veludo-de-Oliveira et.al, 2006). According to Veludo-de-Oliveira et.al (2006), laddering is "particularly suitable to bring out people's goals, values, and dimensions" (p.628). Thus, 
this technique could be employed within the repertory grid technique for exploring the participants' personal constructs further.

Constructs consist of super ordinate constructs which a person thinks as the main constructs so they are important while subordinate constructs are less important ones. The process of laddering consists of laddering up and laddering down. Laddering up is done to obtain an understanding of super ordinate constructs by asking the participants to choose their preference toward two poles of their constructs. Whereas laddering down is for revealing subordinate constructs which is done by breaking down the general constructs into their constituent parts and by asking the participants more detail on how the two poles of constructs are different (Stewart \& Stewart, 1981; Terrill \&Filtman, 2002).

In the process of repertory grid interview, there is a certain structure but it is flexible across all interviews. Therefore, it can be seen as semistructured interview (Terrill \&Flitman, 2002). In addition, they explain that this can be happened in the laddering process in which the researcher investigates any relevant areas as they arose. In other words, this kind of interview enable researcher to focus on particular or specific elements- the objects or entities- and then the researchers are able to elicit particular constructs- the attributes of the objects or entities- of those elements.
Furthermore, rich qualitative data could be obtained by using the repertory grid technique which is combined with the laddering technique. During the ladderingprocess, the participants may elaborate their own opinions regarding the topics under study. As Terrill and Filtman (2002) describe one of the benefits of this method that "in qualitative research, repertory grid can be used to gather further information about the context and meaning of a particular construct" (p.4). This means that the researcher is able to deeply explore the meaning of the participants' personal constructs using the constructs elicitation techniques.

\section{HASIL DAN PEMBAHASAN}

An interview instrument which employs repertory grid technique should be designed prior to the main study. To develop the modified the repertory grid instrument, interview trials should be undertaken to find out the effectiveness of this technique and its instrument for the research purposes. In other words, it is a kind of a trial and error effort and a recycling process for accomplishing the unexpected problems during the interview process.

Within the interview trials, there are somesteps which should be conducted to develop the instrument that is going to be suitable for the participants of the research. They are:

1) Taking notes of the problems encountered

2) Analysing the problems encountered 
3) Designing the plans for the amendments

4) Taking notes of the effectiveness of the amendments made.

Before conducting the interview trials, first of all, the researchers have to determine the set of elements. In selecting the type of element to be used in a grid, there are two important factors that should be considered (Fransella et al. 2004, p.18) as follow:

a. The element should be within the range of convenience of the constructs used.

b. The element should be representative of the area being investigated.

To define the elements sets, there are four ways of getting them (Jankowicz, 2004). The first one is by offering an element set in which the interviewers determine the element set in advance of the interview, with no input from the interviewee. The second one is elements are negotiated between the interviewers and the interviewee. It is done by naming the category, in which the interviewers would name the category into which the elements should fall, but leave it up to the interviewee to name the actual elements. The third one is elicited the elements by using element creation questions as the interviewers prepare a list of questions to which the answers will be the elements. The fourth one is the interviewers let the interviewee choose the elements.
If the researchers decide to get the element set by offering the elements to the participants, the researchers determine the element set in advance of the interview, without input from the participants. The reason for offering the elements is because by supplying elements in grid interviews (though introducing a degree of researcher intrusion) has the advantage of being more efficient in terms of time and effort. It also ensures that the participants could focus their construal on specific issues for investigation. Furthermore, when it is used as a common denominator, supplied elements allow different grids to be compared for further analysis (Jankowicz, 2004; Stewart \& Stewart, 1981).

After the elements and their number had been set, the researchers have to choose the methods of construct elicitation. There are five methods that Fransella et al. (2004) describes for constructs elicitation. They are by triads of elements(also referred to as triadic method of elicitation), dyads of elements, laddering, constructing pyramids and the self-characterisation.

The classical method of construct elicitation istriads of elements. Actually, according to Fransella et al. (2004), "there is nothing sacrosanct about the triad" (p. 28).However, the researchersmay use this most common triadic comparison because it is based on Kelly's theory on how constructs are first formed. Triadic comparison is useful particularly for the interviews 
which deal with the mental capacities of the participants who have intellectual capability on the topics under study. On the other hand,dyads which present two elements to the respondents may be considered too simple and it is better to be used with children (Allison, 1972 in Terrill and Filtman, 2002). Therefore, triadic method could be employed by presenting three elements and then the participants are asked to identify a way in which two of those three elements are similar and different from the third.

When the element set and elicitation techniques have beendefined, the researchers then may conduct the first interview trial. During the interview trials process, participants' comments while articulating their constructs should be recorded and notes should be taken to record their reasoning behind the choices between similar and different elements. However, researchers should be aware whether participants are familiar with this technique or not. If the participants never have experiences of this technique, theyshould be trained in the process of eliciting personal constructs by conducting an 'explanatory preactivity'. This activity could be done by using an example of the triad which presenting three elements that are not related to the topic under study and ask the participants to choose two similar elements and then ask them why the two elements are similar and they are different to the third element. Once participants are familiar with thetriadic method, the repertory grid instrument is ready to be employed for the interviews.

Any difficulties that could be encountered during the first interview trial process for eliciting the participant's personal constructs should also be noted and the amendments should be designed for the next interview trial. For example, during the first interview trial, the participants are confuse or cannot answer the given questions. They mayeven ask for clarification to the interviewers about certain terms used in the questions. This problem should be noted and the researcher should refine the interview question to solve this problem encountered.

The following interview trial shouldaddressthe previous amendments made and note down their effectiveness. If other problems occur, they should be noted once again and then the researchers should consider further refinements of the developed instrument. The interview trials should be undertaken until all of the encountered problems have been resolved and the modified repertory grid instrument is then ready to be used.

\section{KESIMPULAN DAN SARAN}

The interview instrument may employ the principles of repertory grid technique. However, the researchers should consider any difficulties in exercising this technique. Thus, interview trials are beneficial for identifying the problems which may be encountered by the researchers in the 
main study. Researchers may design the interview instrument which does not adopt the whole principles of the repertory grid technique interview because of the adjustments to the current participants' conditions. The main point to consider is that the developed instrument should become a usefultool to help the participants formalizing their ideas, hypotheses or constructs system regarding the topics under study and then explain their personal constructs by using their own language.

It is believed that the instrument which has gone through interview trials for several times will be effective enough instead of asking participants directly with the designed questions which their wordings confusing the research participants. In addition, the participants may not be ready to answer the question automatically due to the complex elements in the content of the topics under study as they may need time for reflections based on their own knowledge and experiences.

The instrument which is developed through interview trials is called as 'the modified repertory grid' since it is developed based on the principles of repertory grid technique but it is adjusted to meet with the purpose of the researchers' studies and the participants' conditions. The analysis of the interviewtrials may indicate that this modified repertory grid instrument is effective enough not only for the researchers but also for research participants.The developed instrument should allow the researchers exploring the topics under study. Furthermore, it should help the researchers to go deeper into eliciting more complex cognitions which are represented in the research participants' personal constructs.

\section{UCAPAN TERIMAKASIH}

Thanks to Dr. Christopher Conlan, BA, Dip LangStud, Dip RSA, M.A, Ph.D. (FRSA) who supervised and helped the author during the development ofher own modified repertory grid instrument.

\section{DAFTARPUSTAKA}

Borg, S. (2006). Teacher cognition and language education: research and practice. London: Continuum.

Beail, N. \&Beail, S. (1985). Evaluating dependency. In N. Beail (Ed.) Repertory grid technique and personal constructs: applications in clinical and educational settings London: Croom Helm.

Coshall, J.T. (2000). Measurement of tourists' images: the repertory grid approach. Journal Travel Research 39.

Down, R.M. (1976). Cognitive mapping and information processing: A commentary: In Moore, G.T. \& Colledge, R.G. (Eds.).Environmental knowing: Theories, research, and methods. Stroudsburg Pa: Dowden, Hutchinson \& Ross.

Elander, J. (2003) Student assessment from a psychological perspective. 
Psychology Learning and Teaching, 3(2): 114-121.

Fransella, F., Bell, R.\&Bannister, D. (2004).A manual for repertory grid technique (Ed.2). Sussex: John Wiley \& Sons Ltd.

Jankowicz, D. (2004). The easy guide to Repertory Grids. Queensland: John Willey and Sons.Inc.

Kelly, G.A. (1955). The Psychology of Personal Constructs, vol 1 and 2. Norton, New York: University Press.

Kelly, G.A. (1969). The autobiography of a theory. In B.A. Maher (Ed.), Clinical psychology and personality: The selected papers of George Kelly. New York: Krieger.

Kurz, T. L. (2011). Discovering features of web-based algebraic tools via data analysis support technology integration in mathematics education. Journal of Curriculum and Instructions, 5 (1).

Goffin, K. (2002), Repertory grid technique, in Partington, D. (Eds), Essential Skills for Management Research, London: Sage Publications.

Terrill, BJ \& Flitman, A (2002), 'Using Repertory Grid Analysis to gather qualitative data for information systems research' in Proceedings of The Thirteenth Australasian Conference on Information Systems (ACIS), Melbourne: Australia,

Stewart, V. and Stewart, A. (1981).

Business applications of
Repertory Grid.London: McGraw-Hill.

Veludo-de-Oliveira, T, M., Ikeda, A.A. \& Campomar, M.C. (2006). Discussing Laddering Application by the Means-End Chain Theory. The Qualitative Report, 11(4), 626-642. 